\title{
Late Cretaceous extension overprinting a steep belt in the Northern Calcareous Alps (Schesaplana, Rätikon, Switzerland and Austria)
}

\author{
Nikolaus Froitzheim - Sebastian Weber • \\ Thorsten J. Nagel • Tobias Ibele · Heinz Furrer
}

\begin{abstract}
The Triassic to Cretaceous sediment succession of the Lechtal Nappe in the western part of the Northern Calcareous Alps (NCA) has been deformed into large-scale folds and crosscut by thrust and extensional faults during Late Cretaceous (Eoalpine) and Tertiary orogenic processes. The following sequence of deformation is developed from overprinting relations in the field: (D1) NW-vergent folds related to thrusting; (D2) N-S shortening leading to east-west-trending folds and to the formation of a steep belt (Arlberg Steep Zone) along the southern border of the NCA; (D3) E-W to NE-SW extension and vertical shortening, leading to low-angle normal faulting and recumbent "collapse folds" like the Wildberg Syncline. D1 and D2 are Cretaceous in age and predate the Eocene emplacement of the Austroalpine on the Penninic Nappes along the Austroalpine basal thrust; the same is probably true for D3. Finally, the basal thrust was deformed by folds related to out-of-sequence thrusting. These results suggest that the NCA were at least partly in a state of extension
\end{abstract}

N. Froitzheim $(\bowtie) \cdot$ T. J. Nagel

Steinmann-Institut, Universität Bonn, Poppelsdorfer Schloss, D-53115 Bonn, Germany

e-mail: niko.froitzheim@uni-bonn.de]

S. Weber

Institut für Geowissenschaften, Universität Freiburg,

Albertstraße 23b, D-79104 Freiburg, Germany

T. Ibele

Department of Geosciences, University of Fribourg,

Chemin du Musée 6, Pérolles, CH-1700 Fribourg, Switzerland

H. Furrer

Paläontologisches Institut und Museum, Universität Zürich,

Karl-Schmid-Strasse 4, CH-8006 Zürich, Switzerland during the sedimentation of the Gosau Group in the Late Cretaceous.

Keywords Northern Calcareous Alps - Cretaceous . Tectonics · Folding · Gosau basins

\section{Introduction}

The Northern Calcareous Alps (NCA) form the frontal part of the Austroalpine Nappe system (Fig. 1) and represent a classical thin-skinned thrust-and-fold belt that was imbricated during the Eoalpine orogeny in the Cretaceous and was later, in the Paleogene, refolded while being thrust over the structurally deeper Penninic units (Linzer et al. 1995; Eisbacher and Brandner 1996; Neubauer et al. 2000; Behrmann and Tanner 2006). In the Central Austroalpine Nappes, south of the NCA, a period of extensional faulting in the Late Cretaceous (ca. 80-67 Ma) separated Cretaceous from Paleogene thrusting (Krohe 1987; Ratschbacher et al. 1989; Froitzheim et al. 1994; Fügenschuh et al. 2000; Rantitsch et al. 2005). Very similar processes affected the internal part of the Western Carpathians (Janák et al. 2001). Late Cretaceous extension caused the formation and rapid subsidence of the Late Cretaceous to Paleogene Gosau basins in the Central Austroalpine (e.g. Kainach Basin; Neubauer et al. 1995; Willingshofer et al. 1999). Whereas the extensional character of the Central Alpine Gosau basins is generally accepted, controversial interpretations exist for the Gosau basins in the NCA, as resulting either from extension (Ortner 1994; Wagreich and Decker 2001) or from thrusting (Ortner 2001, 2003, 2007). If the latter is true, the NCA developed in a fundamentally different way than the Central Austroalpine units (Ortner 2001). On the other hand, individual thrust sheets of the western NCA can 
be followed into the Central Austroalpine units further south, which speaks against a fundamental separation between these two parts of the Austroalpine (Nowotny et al. 1992; Nagel 2006). In order to better understand the relation between the NCA and the Central Austroalpine and contribute to a better understanding of the Late Cretaceous tectonic processes in the NCA, we studied the Alpine deformation of Triassic to Cretaceous sediments in the Lechtal Nappe (NCA) in the area of Schesaplana (Fig. 2), located close to the border between the NCA and the Central Austroalpine.

The large-scale, well-exposed folds of the Schesaplana area have been the subject of geological studies already for a long time (Ampferer 1933, 1934; Arni 1933; Schmidegg 1955; Reithofer et al. 1964; Oberhauser 1970; Weh 1998; Ibele and Behrmann 2007). The most spectacular of these folds is the Wildberg Syncline north of Schesaplana (Fig. 3, profile C-D), a recumbent, northward-opening syncline with a shallowly plunging, east-west axis. Further south-east, overturned (downward-facing) folds with steeply east-plunging axes occur. Other folds in the area trend east-west and are in an upright position. In addition, the area exhibits faults of several generations, including both high-angle and low-angle normal faults. The geometric relationships between the different folds on one hand, and between folds and faults on the other, are still unclear. In many of the older studies cited above, the authors made the mistake to correlate certain strike directions of fold axes with certain deformation phases, neglecting the fact that if an older fold is folded around a younger one, the older fold axis may attain strongly variable orientations depending on its position with respect to the younger fold. In this article, we will use structural field observations on map and outcrop scale to develop a relative time sequence of deformation, keeping in mind the geometric rules of fold overprinting as developed by Ramsay and Huber (1987).

\section{Regional geologic framework}

The Austroalpine Nappes represent that part of the Alpine orogen which developed from the south-eastern continental margin of the Piemont-Ligurian (South Pennnic) Ocean and which was affected by thrusting, folding and partly metamorphism during the Cretaceous. The Austroalpine Nappes may be subdivided into the Lower Austroalpine, comprising several relatively small thrust sheets along the base of the Austroalpine Nappe edifice, and the overlying Upper Austroalpine. The latter is in turn subdivided into the Central Austroalpine to the south and the NCA to the north. The NCA are formed exclusively by unmetamorphic to very-low-grade metamorphic Permian to Cretaceous sedimentary and very minor volcanic rocks, whereas the Central Austroalpine includes also older rocks with a variably strong Variscan to Permian metamorphism and
Fig. 1 Tectonic sketch map of the north-western part of the

Eastern Alps. Frame indicates study area. $A F$ frontal thrust of the Alps, $A Z$ Arosa Zone, $B S$ Bündnerschiefer, $E W$ Engadine Window, $F N$ Falknis Nappe, $P F$ Prättigau Flysch, PZ Phyllitgneis Zone, $S N$ Sulzfluh Nappe

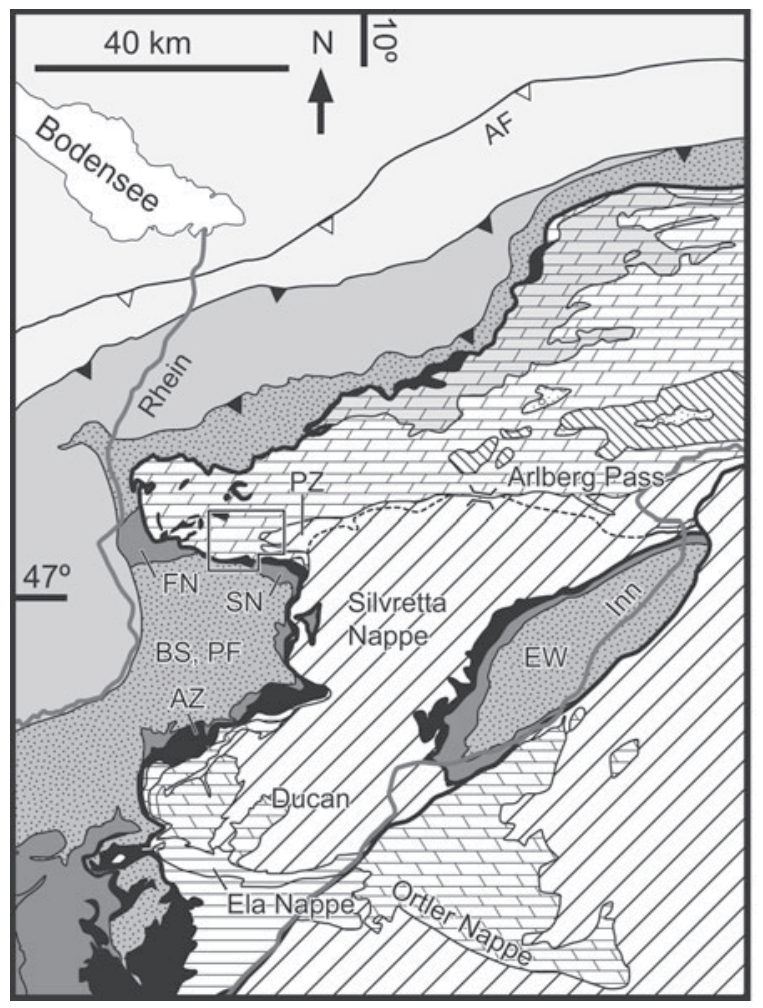

Northern Calcareous Alps

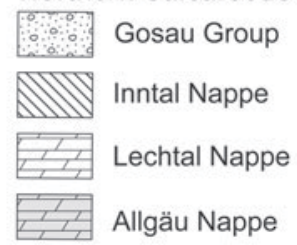

Central Austroalpine Nappes

Mesozoic Cover

C1 Basement

Lower Austroalpine Nappes

Upper Penninic Nappes

Middle Penninic Nappes

Lower Penninic Nappes

Helvetic Nappes

Molasse Basin 


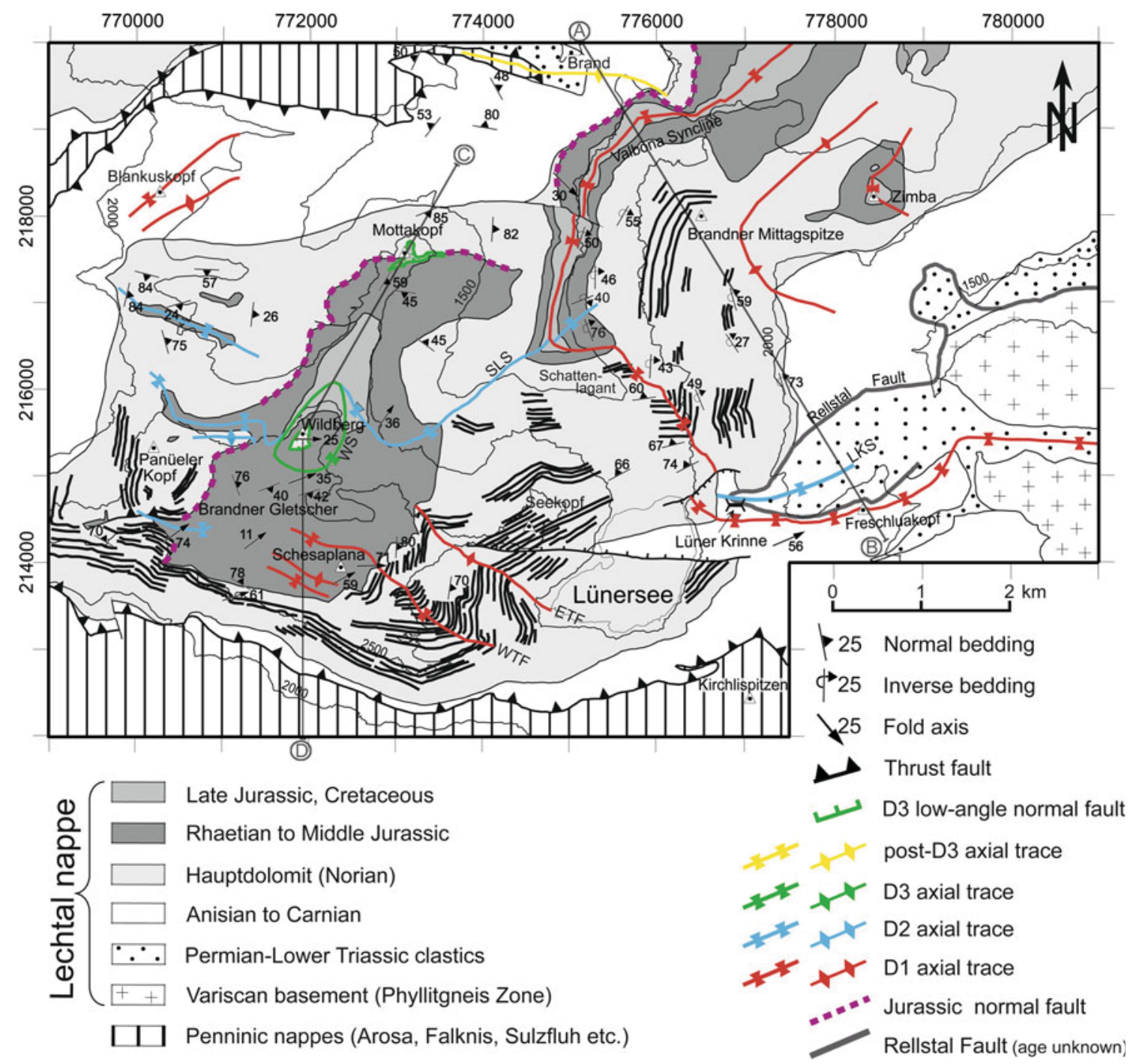

Fig. 2 Tectonic map of the study area, partly based on Heissel et al. (1965). ETF Eastern Totalp fold, LKS Lüner Krinne Synform, SLS Schattenlagant Synform, WS Wildberg Syncline, WTF Western Totalp fold. For location, see Fig. 1

equally variable Alpine metamorphism (Hoinkes et al. 1999).

The study area is close to the western end of the NCA (Fig. 1). This end is not primary but erosional as can be seen from the existence of small outliers of NCA rocks ca. $60 \mathrm{~km}$ further west in Central Switzerland (Trümpy 2006). Of the three nappes that constitute the western part of the NCA (from base to top: Allgäu Nappe, Lechtal Nappe and Inntal Nappe), only the Lechtal Nappe occurs in the study area. Schesaplana is a large plateau-like massif at the Austrian-Swiss border, reaching 2,964 $\mathrm{m}$ at the highest point and built up mainly by Norian dolomite and Rhaetian shale and limestone of the Lechtal Nappe. Along the foot of the south face of Schesaplana, the overthrust of the Lechtal Nappe over Penninic Nappes (from top to base: Arosa Zone, Sulzfluh Nappe, Falknis Nappe and Prättigau Flysch) is exposed. The Penninic Nappes reappear north of
Schesaplana in the core of an east-west-striking antiformal window (northern margin of the map area, Fig. 2). Such windows occur at several places in the western Lechtal Nappe and are related to north-west-directed out-ofsequence thrusts postdating the emplacement of the Austroalpine on the Penninic Nappes (Fig. 1; Oberhauser and Rataj 1998). Near the eastern margin of the map area, Permian to Early Triassic clastic sedimentary rocks of the Lechtal Nappe are in transgressive depositional contact with Variscan metamorphic basement rocks (Phyllitgneis Zone). This contact is now in most places subvertical or overturned and locally faulted, e.g. by the Rellstal Fault (Fig. 2). Nevertheless, it appears that the Phyllitgneis Zone represents the basement on which the sediments of the Lechtal Nappe were originally deposited (Bertle et al. 1979). Still farther east, the Phyllitgneis Zone borders the basement rocks of the Silvretta Nappe, a large thrust sheet 
of the Central Austroalpine. The Phyllitgneis Zone and the Silvretta Nappe are not separated by a major fault contact and are lithologically similar, only the Phyllitgneis Zone has been more strongly affected by Alpine deformation and diapthoresis (Frank 1987; Nowotny et al. 1992). Hence, the Lechtal and Silvretta Nappes may be regarded as two parts of the same major thrust sheet (Nagel 2006).

\section{Sediment succession (Lithostratigraphy after Furrer and Ortner 2007; old names in brackets)}

The sedimentary succession (Fig. 4) begins with Permian to Early Triassic clastic red beds of the Präbichl and Fuorn formations ("Verrucano" and "Buntsandstein"). The Anisian is represented by carbonates of the Reichenhall and Reifling formations ("Alpine Muschelkalk") and the Ladinian by shale and marl of the Partnach Formation, followed by limestone alternating with shale of the Arlberg Formation. The overlying Northalpine Raibl Group of Carnian age includes limestone, dolomite, cargneule, gypsum, sandstone and shale. The evaporites represent an important décollement horizon. The Norian Hauptdolomit Group reaches $1.5-2.0 \mathrm{~km}$ of thickness and represents the most competent part of the succession. The Rhaetian Kössen Formation includes a shale-dominated succession at the base (Alplihorn Member), followed by shale-carbonate cycles with coral banks (Schesaplana and Ramoz Members), and finally massive reef limestones (Zirmenkopf Limestone; Furrer 1993). The base of the Kössen Formation forms another décollement horizon.

The Early Jurassic is developed in different facies, either hemipelagic, basinal, silicious marls and limestones with intercalated calciturbidites, breccias and megabreccias (Allgäu Formation), or condensed submarine-high sediments including shale, siltstone, oolite, crinoidal limestone and nodular micritic limestone (Adnet Formation; Furrer 1993; MacRoberts et al. 1997). These often rest unconformably on different members of the Kössen Formation or fill neptunian dykes in rocks of the Kössen Formation and even in the Hauptdolomit. The youngest part of the Allgäu Formation is represented by red marls of Early Toarcian age ("Ziegelrot-Serie"; Jacobshagen 1965; Eberli 1985, 1988). Sediments of Late Toarcian to Middle Jurassic age are absent. Red micritic limestone with chert nodules of the Ruhpolding Formation ("Radiolarit") documents condensed pelagic deposits of the Late Jurassic. The following grey, marly, pelagic Ammergau Formation ("Aptychus Limestone") of Tithonian to earliest Cretaceous age grades upward into shales with turbiditic sandstone layers of the Lech Formation ("Kreideschiefer"), the youngest part of which is Early Turonian (Oberhauser 1963).

\section{Structures related to Jurassic rifting}

Rhaetian and Jurassic rocks are exposed with a relatively large thickness (Kössen Formation: ca. 220 m; Allgäu Formation: ca. 200 m; Eberli 1985; Furrer 1993) in the area between Schesaplana and Mottakopf. A north-north-east striking, east-dipping normal fault of Jurassic age, overprinted by Alpine deformation, forms the western border of this outcrop area against the Hauptdolomit massif of Panüeler Kopf. On the east side of the fault, the Kössen Formation is complete and the basinal Allgäu Formation includes breccia and megabreccia layers as well as slumped horizons (Eberli 1985), indicating the vicinity of a synsedimentary fault. On the west side, relics of Kössen Formation are found within synclines in the Hauptdolomit. In one locality on the west side of the fault near Panüeler Kopf, sedimentary breccias with a matrix of Early Jurassic limestone are found filling neptunian dykes within the Hauptdolomit, showing that the Kössen Formation had been largely or completely removed during the Early Jurassic, allowing the neptunian dykes to penetrate into the Hauptdolomit. Consequently, the western block represents the footwall of the Jurassic normal fault where parts of the Kössen Formation were eroded, and the eastern block, the hanging wall. In spite of the Alpine overprint, the fault generally retained its normal character, with older rocks (Norian to Rhaetian) in the footwall juxtaposed against younger rocks (Rhaetian to Jurassic) in the hanging wall, the contact cutting the bedding of the Hauptdolomit generally at high angles. East of Mottakopf the further continuation of this fault is unclear, but it probably continues towards north-east in the western limb of the Valbona Syncline (Figs. 2, 3).

Eberli $(1985,1988)$ also inferred the existence of a system of east-dipping Jurassic normal faults in the western Schesaplana massif from the thickness and facies distribution in the Early Jurassic sediments. He dated the fault activity biostratigraphically into the Sinemurian to Pliensbachian. May and Eisbacher (1999) reconstructed similar east-dipping Jurassic normal faults further east in the Lechtal Nappe, near Arlberg Pass. The Early Jurassic faulting divided the Hauptdolomit platform into tilted blocks. It is obvious that this fragmentation had a severe impact on the geometrical evolution of the Alpine folds, making them strongly non-cylindrical. A system of eastdipping Early Jurassic normal faults, active from the Hettangian to Pliensbachian, existed also in the Central and Lower Austroalpine Nappes further south (Ortler and Ela Nappes; Eberli 1988; Froitzheim 1988; Conti et al. 1994). The similar orientation of faults in the Schesaplana area of the NCA and in the Central Austroalpine units further south suggests that no important differential rotation affected these units during the Alpine orogeny. 
Fig. 3 Cross-sections of the study area. SLS Schattenlagant Synform, VS Valbona Syncline, WS Wildberg Syncline. Profile traces are indicated in Fig. 2. Patterns, colours and abbreviations are the same as in Fig. 2
A
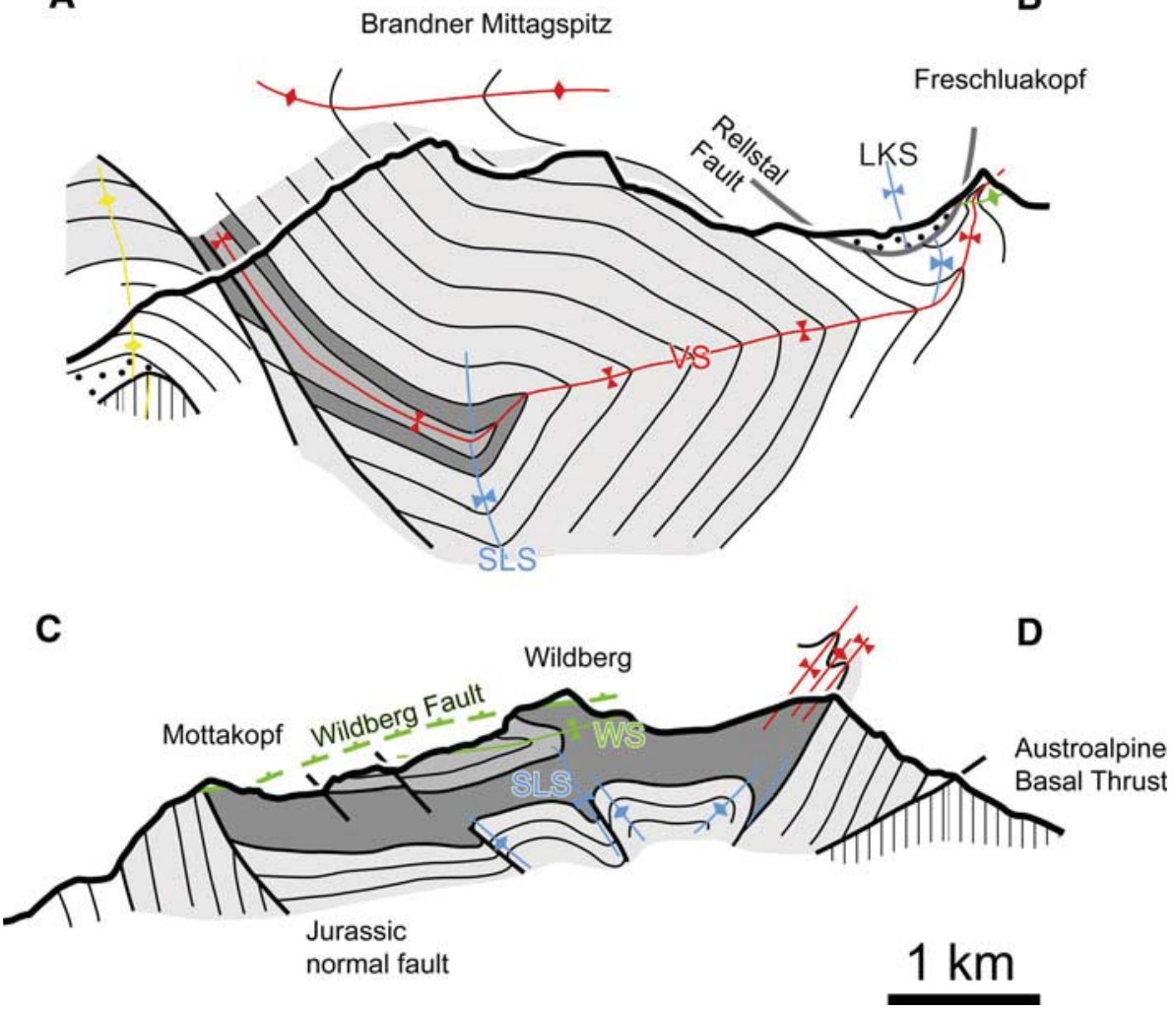

Folds and faults of the Schesaplana area

Valbona Syncline (D1)

The most prominent fold in the north-eastern part of the map area is a north-east-trending and north-west-facing syncline, the Valbona Syncline (Reithofer et al. 1964; Loacker 1986), also termed Sarotla Syncline (Schmidegg 1955) or Brandnertal Syncline (Weh 1998). At Brandner Mittagspitze, the Norian Hauptdolomit in the upper limb of the syncline is overturned and dips east to south-east at an angle of ca. $50^{\circ}$ (Fig. 3); the axial plane dips south-east at low to moderate angles. The youngest rocks in the core of the syncline are Cretaceous in age (Lech Formation). These can be followed towards south up to the locality Schattenlagant where they end abruptly in a synclinal fold closure, together with the Rhaetian and Jurassic rocks. The bedding of the Norian Hauptdolomit south of the fold closure strikes east-west and dips steeply north. It is connected with the east-dipping, overturned Hauptdolomit at Brandner Mittagspitze mentioned above by a sharp, antiformal syncline with a south-east-trending axial trace and a north-east-plunging axis. This syncline is the continuation of the Valbona Syncline that has been rotated into an overturned position by a younger synform with a SW-NEtrending axial surface, the Schattenlagant Synform. Further south-east, close to the NE end of Lünersee, the axial trace of the Valbona Syncline is offset by a young, south-eastdipping normal fault. On the other side of the fault, it continues for a short distance in the Hauptdolomit and then crosses the stratigraphic base of the Hauptdolomit and enters the evaporites of the Raibl Group. In the same area, the axial surface changes orientation again, from NW-SE striking and NE-dipping between Schattenlagant and Lüner Krinne, to W-E-striking and vertical east of Lüner Krinne. This bend is caused by an open synform, the Lüner Krinne Synform (Fig. 3). The Valbona Syncline is again well exposed at Freschluakopf (Freskalot on older maps), a sharp peak formed by Anisian carbonates (Figs. 3, 5). These carbonates outline an anticlinal synform with an east-west-trending subvertical axial plane (see also Schmidegg 1955) and a shallowly east-plunging axis. In the core of the syncline, shales of the Ladinian Partnach Formation are exposed on the north-west side of Freschluakopf. The antiformal syncline (Valbona Syncline) is overprinted by open folds with north-dipping axial planes (Fig. 5). Based on their orientation, we interpret these folds as D3 (see below). Further east, the axial trace of the Valbona Synform appears to enter the Early Triassic clastics and to continue in an east-west-trending stripe of these clastics bordered by gneissic basement rocks (Phyllitgneis Zone) to the north and south (Fig. 2). Still further east, the stripe of clastics terminates in the basement of the Phyllitgneis Zone. 
Fig. 4 Sediment succession of the Lechtal Nappe in the area of Schesaplana (compiled from Kobel 1969; Harsch 1969; Czurda and Nicklas 1970; Furrer 1993; and others).

Column on the left side shows the patterns used

in Figs. 2 and 3

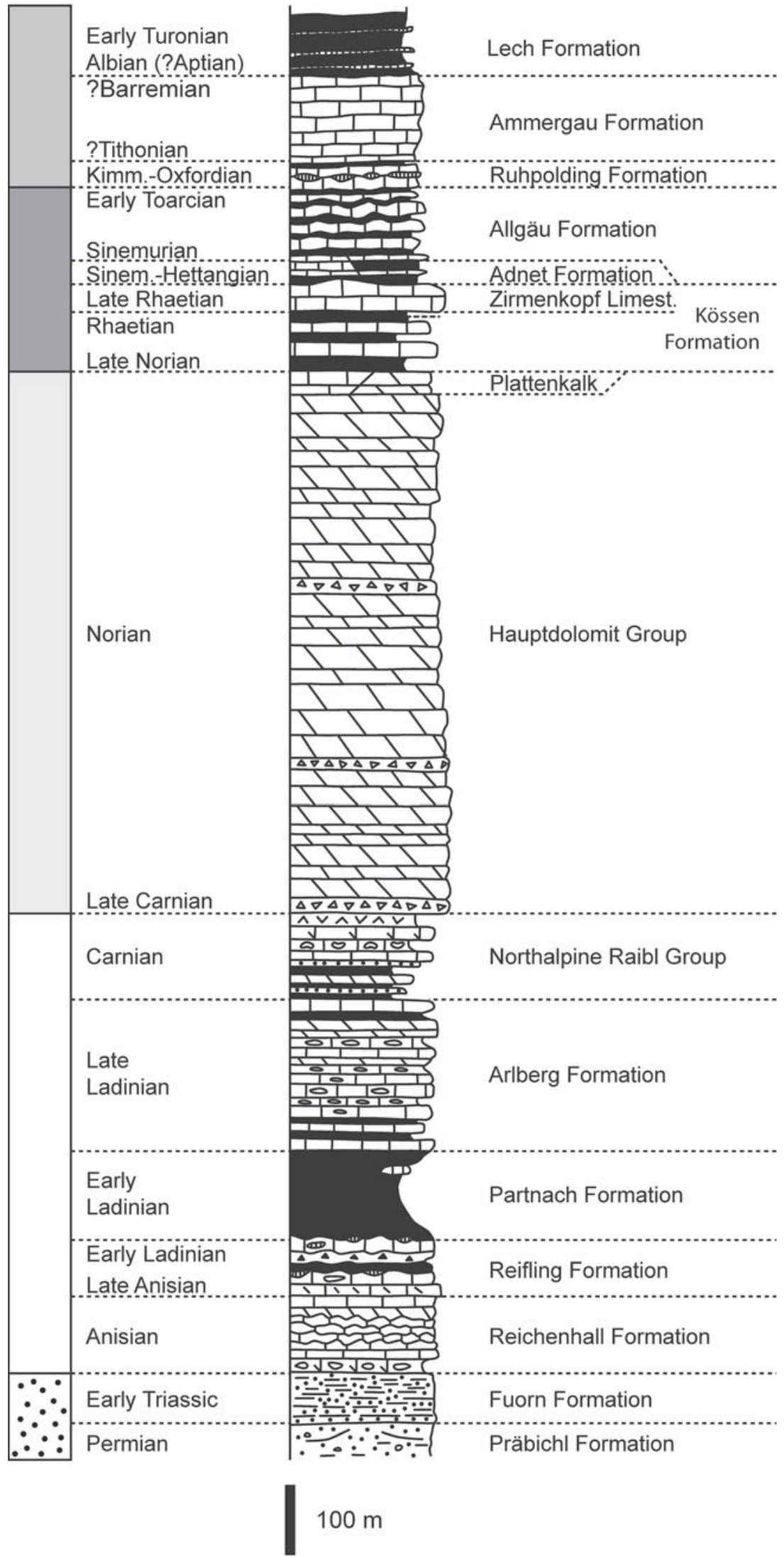



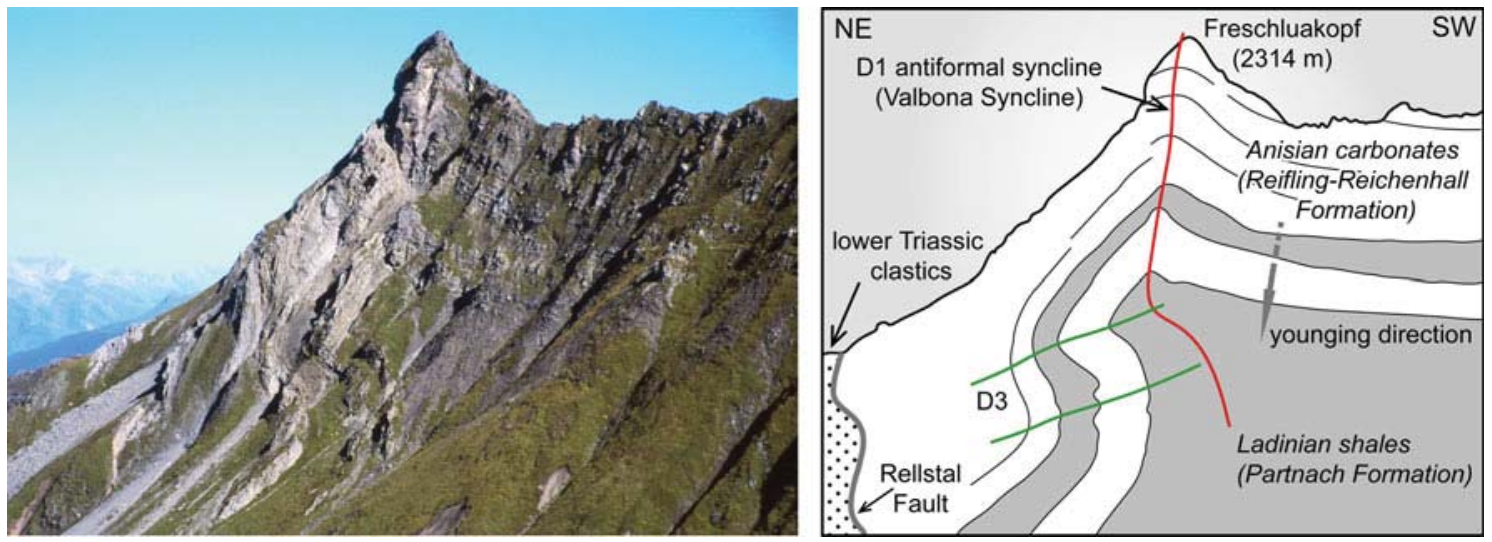

Fig. 5 View of Freschluakopf from the north-west. The upright, antiformal syncline exposed here is interpreted as the overturned continuation of the D1 Valbona Syncline, overprinted by gentle D3 folds

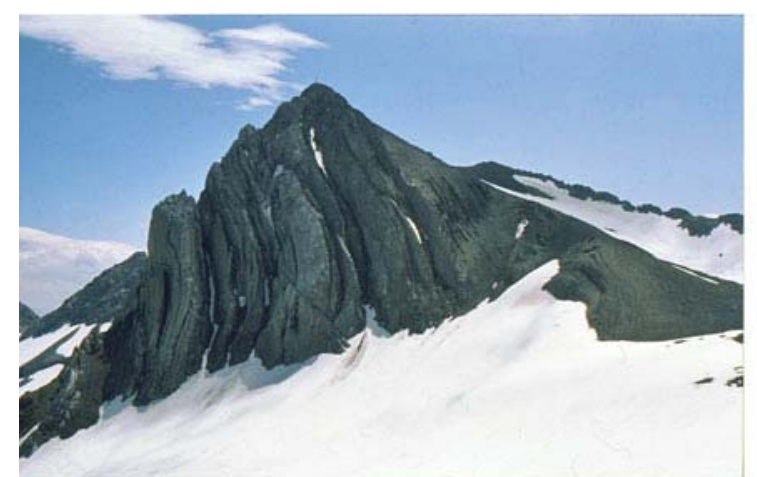

Fig. 6 Summit pyramid of Schesaplana, seen from the west. The cliff is formed by Rhaetian shales and carbonates of the Kössen Formation, generally younging from right to left, and deformed by downward-

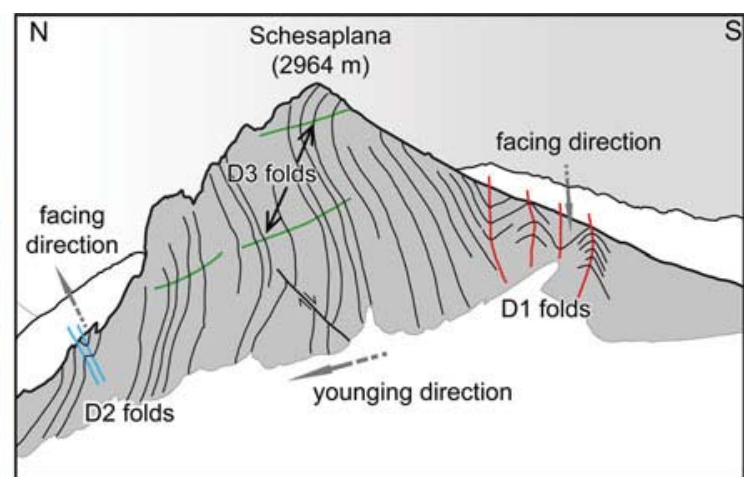

facing D1 folds with steeply east-plunging axes, upward-facing D2 folds with shallowly inclined axes, a gentle D3 undulation, and a minor, late (post-D3), south-dipping normal fault
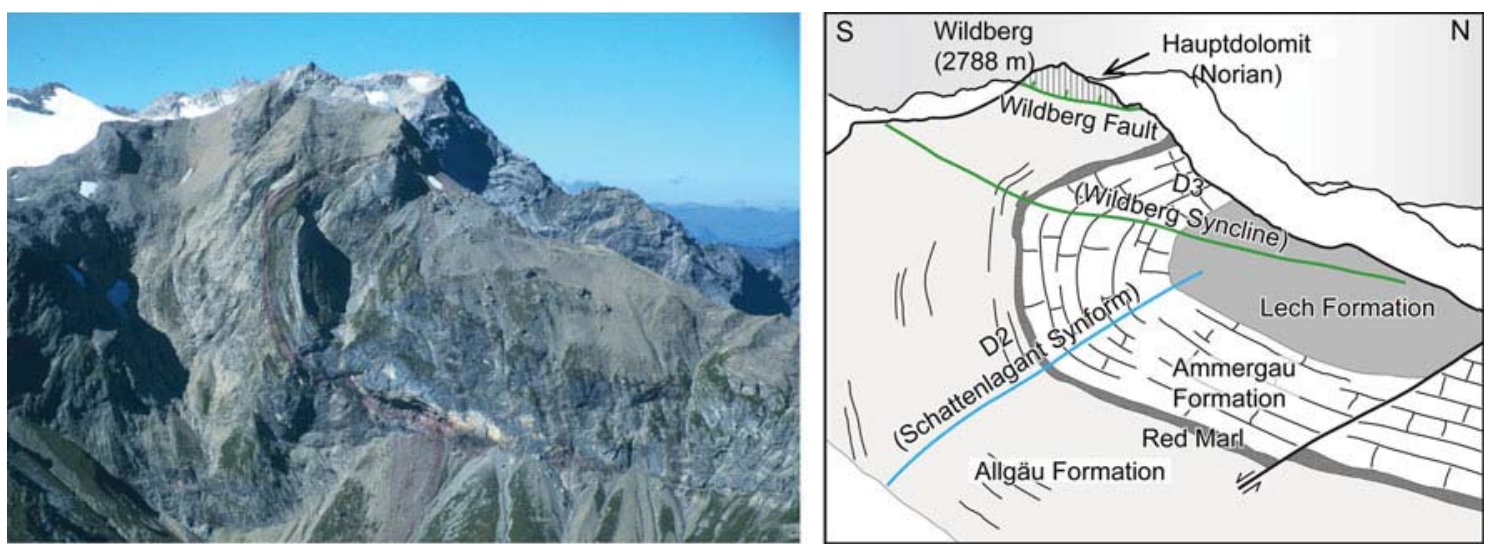

Fig. 7 Wildberg, seen from the east. The summit is an extensional klippe of Hauptdolomit resting on a top-to-the-north-east, low-angle normal fault (Wildberg Fault). The Jurassic to Cretaceous sediment succession is folded around two hinges. The upper one is the D3 Wildberg Syncline. It is interpreted as cogenetic with the Wildberg

We assume that the Valbona Syncline represents the oldest generation of folds in the study area (D1) because it is overprinted by other folds on the map and outcrop scale but does itself not deform any other folds.
Fault, resulting from extensional collapse. The lower hinge is part of the D2 Schattenlagant Synform. Also visible is a south-dipping, latestage (post-D3) normal fault. The slickenside orientation measurements (Fig. 10) were made in the Lech Formation to the right

Other D1 folds

A syncline-anticline pair with steep axes, well visible on aerial photographs (Schmidegg 1955), deforms the 
Hauptdolomit Group between Lünersee and Schesaplana. The syncline and the anticline will in the following be referred to as the Western and Eastern Totalp folds, respectively. The bedding of the Hauptdolomit between the axial traces of the folds is overturned, strikes $\mathrm{N}-\mathrm{S}$ and dips steeply east. East and west of the fold pair, the bedding strikes E-W to NE-SW and is subvertical to steeply northor north-west-dipping. The fold axes consequently plunge steeply NE, and the axial planes strike NW-SE and dip NE as well. The geometry of these folds is the same as for the Valbona Syncline between Schattenlagant and Lüner Krinne. Within the shales of the lower Kössen Formation at Schesaplana (Fig. 6), minor folds with the same geometry and orientation as the Totalp folds occur. They are associated with an axial planar cleavage representing the oldest penetrative deformation structure in these rocks.

In terms of geometry, the Totalp folds resemble a largescale kink band. The limb between the fold hinges is shorter than the two limbs east and west of the fold pair, which means that the fold vergence is towards west. Due to their parallelism with and similarity to the Valbona Syncline, we assume that the Totalp folds represent the same fold generation, D1.

Another D1 syncline-anticline pair occurs in the NW part of the map area at Blankuskopf (Fig. 2; Ibele and Behrmann 2007). In this case, the fold axes trend SW-NE, the axial planes dip SE and the vergence is towards NW. Finally, a D1 anticline and syncline occur in the eastern part of the map area east of the Valbona Syncline. The anticline is located in the Hauptdolomit Formation between Brandner Mittagspitze and Zimba, and the syncline contains the Rhaetian to Cretaceous formations at Zimba. These two folds are vergent towards west.

\section{D2 folds}

Taken together, the D1 axial traces form a westward-convex arc in map view. In the northern part, the folds verge towards north-west and we interpret their orientation as being the original one, related to north-westward shearing during nappe thrusting. In the southern part, however, the folds have been rotated south-side up into steep or even overturned orientations, most notably the Valbona Syncline that has been reoriented into an antiformal syncline at Freschluakopf. We assume that this rotation is associated with a second generation of folds (D2). The most important of these is the Schattenlagant Synform that separates the northern, flat-lying part from the steepened part in the south (Figs. 2, 3). This is an open synform with straight limbs and an inter-limb angle of $90^{\circ}$ to $120^{\circ}$ in the Rhaetian and Jurassic formations. The fold is well defined between the locality Schattenlagant and the eastern side of Wildberg (Fig. 7). Further east, it becomes very open and

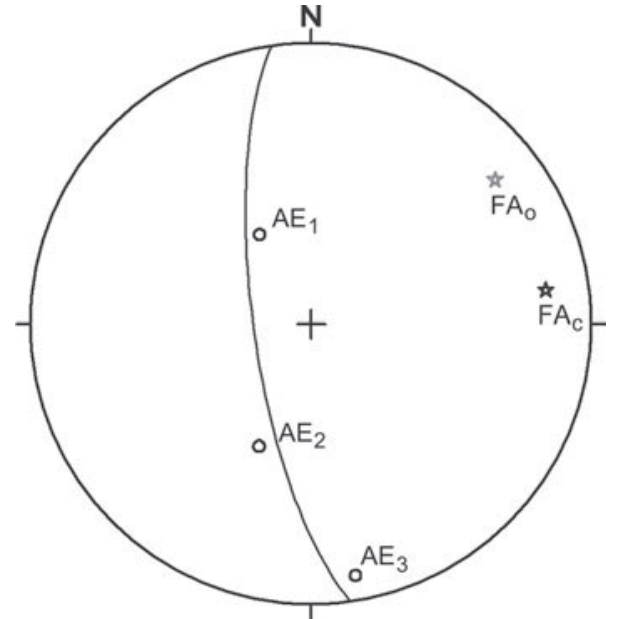

Fig. 8 Lower hemisphere Schmidt representation of the relations between the D1 Valbona Syncline and the D2 Schattenlagant and Lüner Krinne Synforms. $\mathrm{AE}_{1}, \mathrm{AE}_{2}$ and $\mathrm{AE}_{3}$ are poles to the axial plane of the D1 Valbona Syncline north of the Schattenlagant Synform, between the Schattenlagant Synform and the Lüner Krinne Synform, and south of the Lüner Krinne Synform, respectively. The best-fit great circle through these three poles is shown. The pole to this great circle $\left(\mathrm{FA}_{\mathrm{c}}\right)$ approximates the fold axis around which the axial plane of the Valbona Syncline has been folded. For comparison, $\mathrm{FA}_{\mathrm{o}}$ is the hinge line of the Schattenlagant Synform observed in the field in the lower limb of the Valbona Synform. For further explanation, see text

indistinct as it enters the thick Hauptdolomit of the overturned limb of the Valbona Syncline. At Wildberg, the Schattenlagant Synform merges into the Wildberg Syncline (see below; Fig. 7). Further west, we assume that it extends into the syncline north of Panüeler Kopf (Fig. 2). We tentatively assume that the Lüner Krinne Synform belongs to the D2 folds as well because it is similar in orientation to the Schattenlagant Synform. Together, the Schattenlagant and Lüner Krinne Synforms represent the two hinges of a synformal box fold (Fig. 3, profile A-B).

In order to test the hypothesis that the Valbona Syncline has been deformed by the Schattenlagant and Lüner Krinne Synforms, we determined the orientation of the axial surface of the Valbona Syncline in three sectors (Fig. 8): north of the intersection with the Schattenlagant Synform $\left(\mathrm{AE}_{1}\right.$ : azimuth/dip 150/30), between the intersections with the Schattenlagant Synform and the Lüner Krinne Synform ( $\mathrm{AE}_{2}$ : azimuth/dip 23/39) and south of the intersection with the Lüner Krinne Synform ( $\mathrm{AE}_{3}$ : azimuth/dip 350/80). Orientations of AE1 and AE3 were determined from the map (Fig. 2) and profile A-B (Fig. 3), and the orientation of AE2 was determined from bedding orientation measurements in both limbs of the fold, assuming that the axial surface is the bisectrix of the limbs, which seems justified here since folding of the rigid Hauptdolomit layers involves mainly kinking and layer-parallel slip but little ductile strain. We then determined the best-fit great circle 
through the three poles of the axial plane orientations; the pole to this great circle is the axis of the folds that deformed the axial plane. The orientation of the resulting fold axis is 82/17 (azimuth/plunge; FAc in Fig. 8). This fits reasonably well the orientation of the Lüner Krinne Synform (Figs. 2, 3) and the orientation of a hinge line of the Schattenlagant Synform (52/18), which we derived by connecting two points where the axial plane of that synform passes through the contact between Norian and Rhaetian in the lower limb of the Valbona Synform, to the west and south-west of Schattenlagant (Fig. 2). The fit is not perfect, but we find it good enough to support our hypothesis, taking into account that the folded succession includes the thick and hard-to-fold Hauptdolomit and that it had been disrupted beforehand by Jurassic rift faults.

Other folds of the D2 generation occur on the outcrop scale in the Kössen and Allgäu formations between Schesaplana and Wildberg (Fig. 6). They mostly display east-west-trending, vertical to steeply north- or southdipping axial planes. D2 folds deform the D1 cleavage. A D2 syncline with Kössen Formation in the core and Hauptdolomit in the limbs occurs south of Panüeler Kopf. It is associated with a north-dipping thrust (Fig. 2).

Wildberg Syncline (D3)

The Wildberg Syncline is spectacularly exposed on both the western and eastern sides of Wildberg (Fig. 7). On the western side, only one recumbent, southward-closing fold hinge is visible, whereas on the eastern side, the syncline exhibits the geometry of a recumbent box fold with two hinges. The axial plane of the lower hinge can be traced into the Schattenlagant Synform (D2). The upper hinge is sharper than the lower one and shows the same orientation and style as the hinge exposed on the west side. Connecting the upper hinge

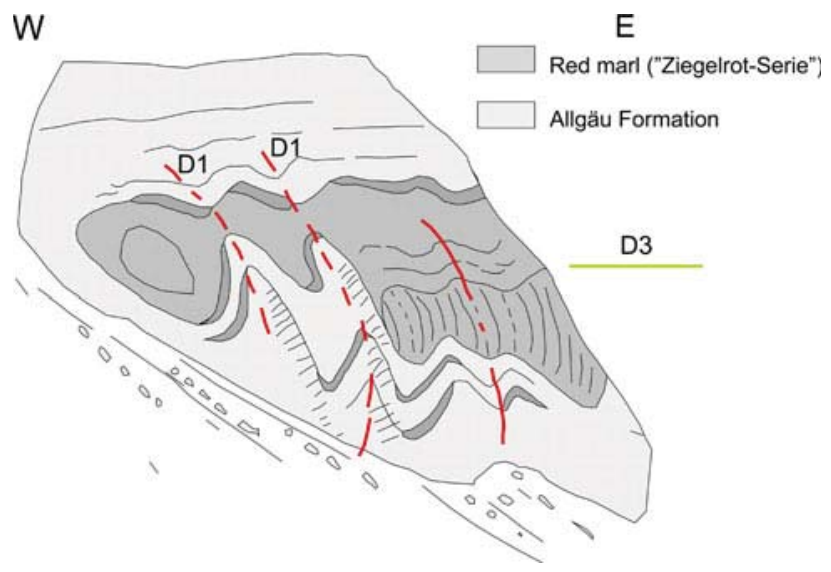

Fig. 9 Field sketch of the hinge of the Wildberg Syncline on the east side of Wildberg, seen from the south. Minor D1 folds and the associated cleavage-bedding intersection lineation (not visible on the sketch) are folded around the D3 hinge on the east side with the one on the west side results in a fold axis plunging $11^{\circ}$ towards east $\left(85^{\circ}\right)$. The fold's axial plane dips shallowly towards north. The Wildberg Syncline has been correlated with the Valbona Syncline by previous authors (e.g. Weh 1998), but outcrop-scale observations at the upper hinge on the east side of Wildberg (Fig. 9) show that it is younger than the Valbona Syncline. In this area, the red marls ("Ziegelrot-Serie") crop out in the core of the syncline. Minor, west-vergent folds with steep axes, associated with an axial planar cleavage, are folded around the subhorizontal hinge of the Wildberg Syncline. The minor folds have the same orientation and vergence as the D1 folds further south, e.g. the Totalp folds. Therefore, they are interpreted as D1, and the Wildberg Syncline must consequently be post-D1. Outcrop-scale observations in several places, most clearly on the west face of Schesaplana (Fig. 6), show that the Wildberg Syncline is also younger than the upright D2 folds and therefore represents a third fold generation, D3. On Schesaplana, open, gentle folds with shallowly north-dipping axial planes occur, which are associated with the Wildberg Syncline. These overprint both the downward-facing D1 folds and the upward-facing D2 folds (Fig. 6). The Wildberg Syncline is the most conspicuous D3 structure. In other places, this deformation is expressed by mere undulations of steep layers, e.g. at Schesaplana or at Freschluakopf (Fig. 5).

Low-angle normal fault at Wildberg

The summit of Wildberg is formed by a klippe of Hauptdolomit resting on rocks of the Allgäu Formation along a

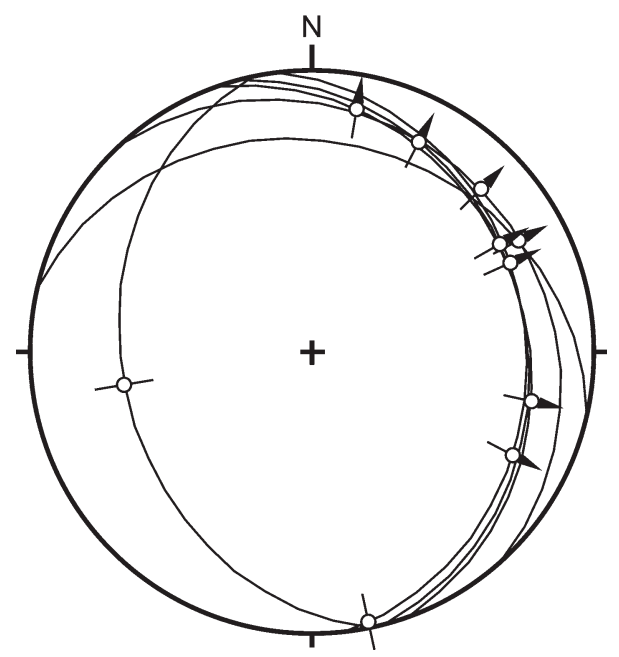

Fig. 10 Orientation data of small-scale faults in slates of the Lech Formation, in the footwall of the Wildberg Fault, indicating predominantly north-east to eastward movement along shallowly dipping normal faults. Great circles: fault planes; open points and short lines: orientation of slickenside lineation; arrows: transport direction of hanging wall as determined by slickenside asymmetry. Lower hemisphere Schmidt projection 
tectonic contact, termed Wildberg Fault in the following (Figs. 3, 7). The Allgäu Formation in the footwall belongs to the overturned limb of the Wildberg Syncline. The fault contact dips shallowly towards north-east. It cuts into the ground again further north at Mottakopf where a klippe of Upper Cretaceous slates (Lech Formation) rests on footwall rocks ranging in age from Norian to Late Jurassic, which belong to the normal limb of the Wildberg Syncline. The large-scale geometry of the Wildberg Fault is most easily explained by normal-fault displacement: at the summit of Wildberg, the Kössen Formation of the inverse limb of the Wildberg Syncline is omitted by the fault, and at Mottakopf, parts of the normal limb are omitted.

The Wildberg Fault itself is mostly covered by debris of the hanging-wall rocks, but its kinematics can be determined from small-scale structures in the Lech Formation in the core of the Wildberg Syncline, located in the footwall in close proximity to the Wildberg Fault (Figs. 7, 10). In these rocks, small-scale faults generally dip shallowly east to north-east, roughly parallel to the Wildberg Fault, and bear fibrous slickenside lineations indicating normal-fault motion towards the east and north-east (between eastsouth-east and north-north-east). These observations confirm the normal-fault character of the Wildberg Fault and constrain the slip direction. The amount of displacement can only roughly be estimated. About $1.5 \mathrm{~km}$ of displacement would be necessary to transfer Hauptdolomit from the area of Panüeler Kopf to its present location at the summit of Wildberg (Fig. 2). The emplacement of Lech Formation on the Wildberg Fault at Mottakopf (Figs. 2, 3) could be explained by the same amount of displacement.

\section{The Rellstal Fault}

The Rellstal Fault occurs in the eastern part of the map area (Figs. 2, 3). In this area, the sediment succession is generally in a subvertical to overturned position. The hanging wall of the fault comprises Permian to Early Triassic clastic sediments and Variscan basement rocks (Phyllitgneis Zone), and the footwall rocks range from Permian-Early Triassic to Norian (Fig. 2). Various parts of the sediment succession are omitted along the fault. The orientation of the fault is highly variable, suggesting that it is a relatively old structure and was deformed after its formation. At Lüner Krinne, the Rellstal Fault is folded by the Lüner Krinne Synform with a NE-striking axis, leading to the steeply north-dipping orientation of the fault at Freschluakopf (Fig. 5), located in the southern limb of the synform. The Rellstal Fault is generally poorly exposed, and during our field survey, we did not find outcrops where the displacement direction and sense could be unambiguously determined. The only ductilely deformed fault rocks we found possibly related to the Rellstal Fault are gypsum mylonites in the Northalpine Raibl Group underlying the fault. In one outcrop near Lüner Krinne $\left(47^{\circ} 03^{\prime} 32.75^{\prime \prime} \mathrm{N}\right.$, $\left.9^{\circ} 46^{\prime} 08.33^{\prime \prime} \mathrm{E}\right)$, such gypsum mylonites have a north-eastdipping foliation (azimuth/dip: 35/48), approximately parallel to the local orientation of the Rellstal Fault, and an east-plunging stretching lineation (azimuth/plunge: 88/30). The shear sense, as indicated by asymmetric porphyroclasts of calcite, is top-to-the-west, which would mean that the Rellstal Fault is a west-directed thrust in its present-day orientation. However, the gypsum mylonites are intensely folded, and it is therefore not entirely clear that the mylonite in this outcrop records the displacement along the fault. Therefore, we leave the age and tectonic significance of the Rellstal Fault open for future studies.

Austroalpine basal thrust

In the southern part of the map area, the basal thrust along which the Lechtal Nappe overlies the Penninic Arosa Zone dips shallowly north. In the north-western part, the basal thrust reappears at the surface in a complex, faulted, antiformal fold structure. The rocks forming the immediate hanging wall of the basal thrust range from the PermianEarly Triassic clastics to the Norian Hauptdolomit. The arrangement of these formations in the hanging wall is irregular, in the sense that there is no systematic decrease of their age in a certain direction. In the southern part of the map area, discordance between the shallowly north-dipping basal thrust and the variously oriented bedding of the hanging-wall formations is obvious (see profile C-D in Fig. 3). This reflects the fact that internal fold structures of the Lechtal Nappe are cut by the basal thrust, at least for the D1 and D2 folds. An age relation between D3 folds and the basal thrust cannot be defined from field observations in this area. We did not undertake to determine the transport direction and sense of the basal thrust. The age of the basal thrust is constrained to Eocene or younger by the occurrence of Paleocene to Early Eocene fossils in the underlying Penninic Falknis and Sulzfluh Nappes (Allemann 1957, 2002).

\section{Late folds and faults}

The youngest generation of folds is represented by the roughly E-W-striking, upright anticline at the northern border of the map area near Brand (Fig. 3, profile A-B). It deforms the Austroalpine basal thrust and leads to the exposure of Penninic units in an elongate window ("Fenster des Brandner Golm"; Reithofer et al. 1964). The fold is related to out-of-sequence imbrication of the Lechtal Nappe after its emplacement on the Penninic Units. The age relation between this fold and the D3 folds is not obvious in the field but may be derived from regional 
Fig. 11 Correlation between deformation phases in the Schesaplana area and in the Lower and Central Austroalpine Nappes of Eastern Switzerland

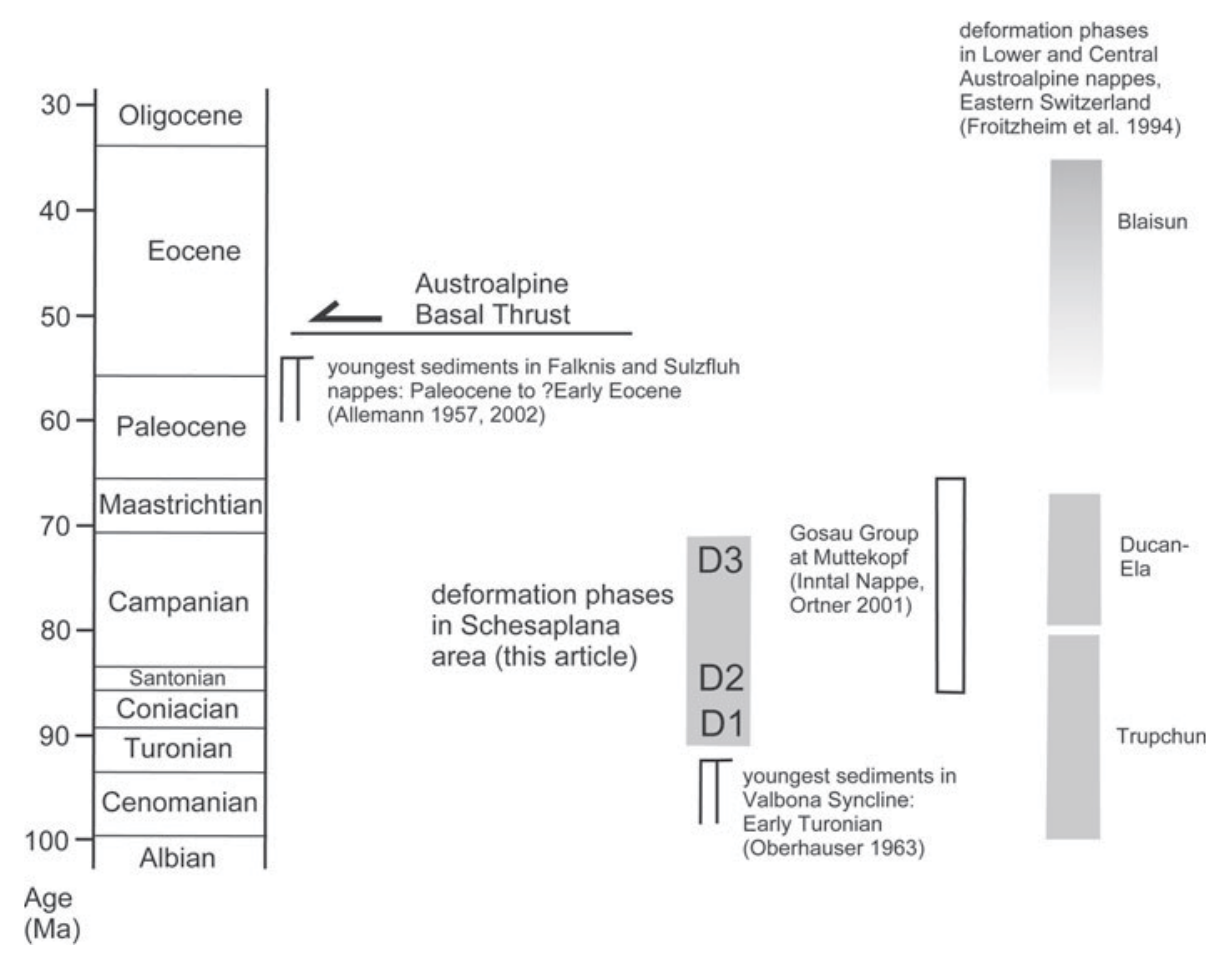

tectonic feature of this part of the Alps. Since D2-steepened layers are truncated by the Austroalpine basal thrust (Fig. 3, profile C-D), D2 deformation in the map area must have preceded the Eocene thrust emplacement of the Austroalpine on the Penninic Nappes. We therefore assume that the Arlberg Steep Zone is of Cretaceous age.

From the situation in the study area, we cannot decide whether the D2 deformation reflects transpression, be it sinistral or dextral, or north-south shortening alone. Observations of other authors suggest a dextrally transpressive framework: along the southern border of the NCA from Arlberg pass to the East, that is, in the Arlberg Steep Zone, Linzer et al. (1995) and Eisbacher and Brandner (1996) described WNW-ESE-striking dextral strike-slip faults kinematically linked to the Cretaceous NW-directed thrusts. By analogy, we tentatively suggest that D1 and D2 in our study area do not represent separate deformation events but two stages of a continuous deformation in a dextrally transpressive framework. Slightly older northwest-vergent folds (D1) could have been compressed in a NNW-SSE direction in a dextral shear zone and refolded (D2).

Ampferer (1933) assumed that the Wildberg Fault was a relief thrust ("Reliefüberschiebung"), that is, a thrust following an erosional relief, and that the hanging wall, the Hauptdolomit klippe at the summit of Wildberg, belonged to the Inntal Nappe (Fig. 1), the highest nappe of the Western NCA which is otherwise not present in the Rätikon area. Based on the structural omission along the fault and on the shear sense of minor faults in the underlying 


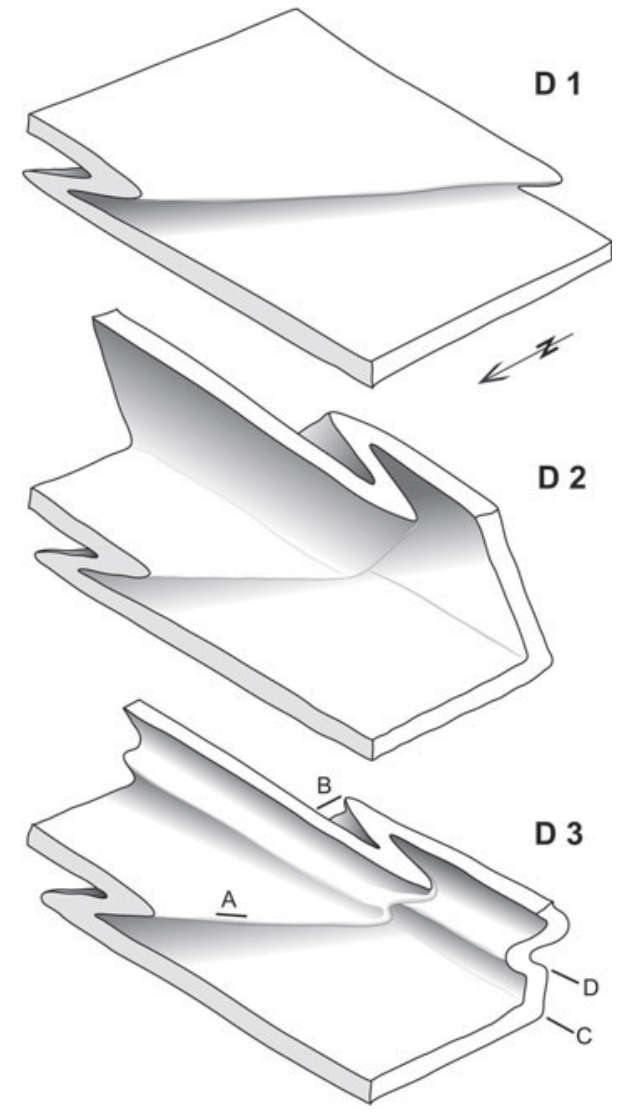

Fig. 12 Block diagrams illustrating the successive stages of folding in the Schesaplana area. Top: north-west-vergent folding during D1. Middle: D2 folding leads to steepening of beds in the southern part of the area. Base: Vertical shortening produces D3 "collapse folds." Concomitant east-west stretching during D3 and low-angle normal faults (D3) are not shown here, for reasons of simplicity. A D1 folds retaining their original orientation, north of the Schattenlagant Synform; B Overturned, antiformal, east-dipping D1 syncline, e.g. Valbona Syncline at Freschluakopf; $C$ Schattenlagant Synform; $D$ Wildberg Synform

Lech Formation, we interpret this fault as a top-north-east low-angle normal fault. The recumbent D3 folds accommodated vertical shortening of previously steepened layers in the southern part of the map area (Fig. 12), that is, they represent "collapse folds" (Froitzheim 1992). The axial planes are parallel to slightly oblique to the Wildberg Fault (Fig. 7). We assume that the area was stretched in an E-W to NE-SW direction during D3 and that this stretching was accommodated by the combined activity of low-angle normal faults and recumbent folds. The latter only formed where the bedding had attained a steep orientation through the D2 folding, that is, in the steep belt in the southern part of the map area. Therefore, we attribute the Wildberg Fault to the same deformation phase as the Wildberg Synline, D3.

The extensional phase D3 postdated Cretaceous thrusting and formation of the Arlberg Steep Zone, and the transport direction of the Wildberg Fault is north-east to east. These are similar relations as observed in the Central and Lower Austroalpine units further south, only that the transport direction there is slightly different, east to southeast. In the Lower Austroalpine, the age of the extensional phase (Ducan-Ela Phase) is constrained to 80-67 Ma (Handy et al. 1996). Extensional faulting in the Ducan-Ela phase also strongly affected the south-western part of the Silvretta Nappe (Ducan area; Froitzheim et al. 1994; Fig. 1). Since the Lechtal Nappe and the Silvretta Nappe are parts of one large thrust sheet, we assume the same age for extensional D3 deformation in the Schesaplana area as in the Ducan area, and hence, that the rocks of the Lechtal Nappe experienced extensional tectonics in the Late Cretaceous (Fig. 11).

Following the Late Cretaceous extension, the NCA were again affected by thrusting in the Eocene when they formed the leading edge of the extensive Austroalpine thrust mass as it was transported over the Penninic Nappes (Fig. 11). The basal thrust was later refolded (antiformal window in the northern part of the map area). Such folds are associated with out-of-sequence thrusts shortening the NCA, possibly in response to stresses arising when the crust of the European continental margin entered the south-dipping subduction zone in the Oligocene and Miocene.

\section{Discussion (II): Late Cretaceous tectonics of the Northern Calcareous Alps}

The NW-vergent D1 folds in the northern part of the study area are best interpreted as fault-propagation folds related to the detachment of the Lechtal Nappe from its original basement. This implies a direction of D1 thrusting towards $\mathrm{NW}$, in accordance with structural analyses of the NCA by Linzer et al. (1995), Eisbacher and Brandner (1996), and May and Eisbacher (1999). In contrast, Behrmann and Tanner (2006) assumed pure N-S kinematics for the middle part of the NCA along the TRANSALP profile, because the structure in that area is "not retrodeformable in NWSE oriented shear." We conclude that NW-directed thrusting is well documented for the western part of the NCA and that further east, the Cretaceous thrusting direction may either be different or overprinting by Tertiary deformation may explain the impossibility of NW-SE retrodeformation.

Our new findings add to the evidence for Late Cretaceous extension in the NCA. The existence of a D3 lowangle normal fault and recumbent "collapse folds" in the Schesaplana area demonstrates that Late Cretaceous extensional faulting affected the westernmost part of the NCA. So far, Late Cretaceous extensional faults were described from the Gosau type-locality in the central part 
Fig. 13 Hypothesis for the paleotectonic situation during the Maastrichtian (70 Ma). Late Cretaceous extension occurs on the inner side of a westwardretreating loop of the Austroalpine-Penninic subduction boundary, decoupled along dextral strike-slip faults in the north and sinistral strike-slip fault in the south. Oceanic crust in grey, continental crust in white. $D$ Ducan area, $G$ Gosau type-locality area,

$S$ Schesaplana area. After Froitzheim et al. (1997) and other sources

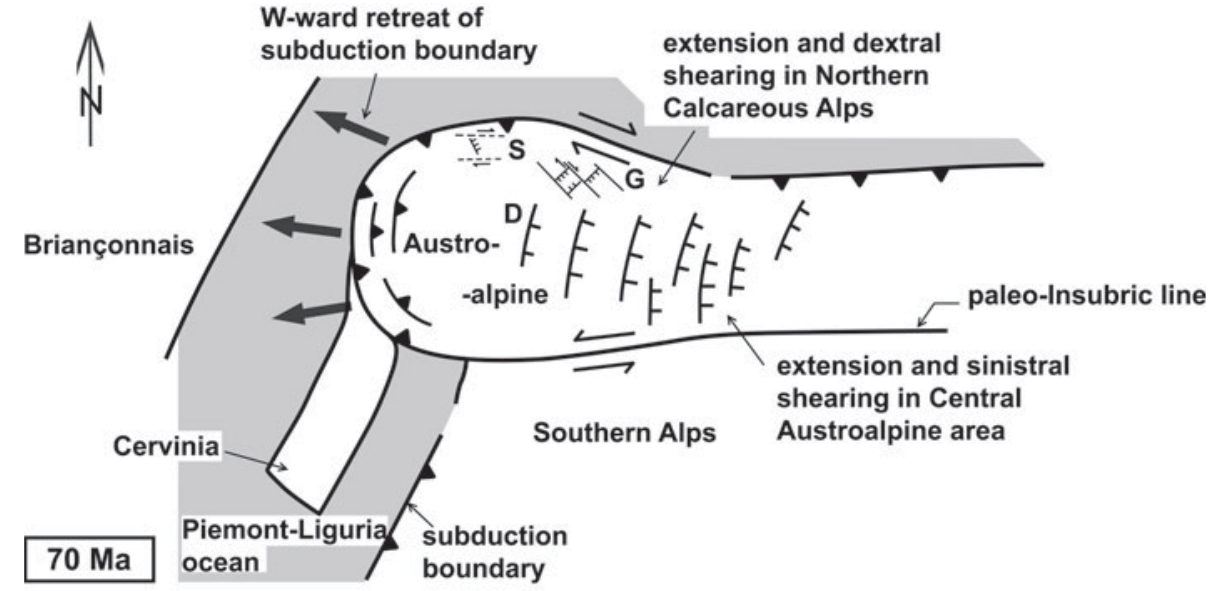

$-500 \mathrm{~km}$ of the NCA where they were active during deposition of the Gosau Group (Wagreich and Decker 2001). These faults accommodated NW-SE to WNW-ESE extension, which differs from the W-E to SW-NE extension direction we derive for the Schesaplana area. Wagreich and Decker (2001) showed that the normal faults in the Gosau area were connected with NW-SE-trending dextral strike-slip faults (Fig. 13). Dextral strike-slip faults in a similar orientation and overstepped by Gosau sediments were also identified by Eisbacher and Brandner (1996). This suggests that the Gosau Basins of the Northern Calacareous Alps formed in a framework of dextral transtension. In our study area, the inferred SW-NE to W-E extension direction of D3 would fit into such a scenario of dextral transtension in an east-west-trending zone. The sequence of deformation in the Schesaplana area would then represent a transition from dextral transpression (D1 and D2) to dextral transtension (D3). This contrasts with the situation further south in the Central Austroalpine. There, both the west-directed thrusting during the Trupchun Phase and the subsequent extension during the Ducan-Ela Phase were kinematically linked to sinistral strike-slip zones, the most important of these being the Paleo-Insubric Line that decoupled the Austroalpine from the Southern Alps (Froitzheim et al. 1997, Handy et al. 2010). Another sinistral shear zone of Cretaceous age affecting the Lower and Central Austroalpine is the Albula Steep Zone along the southern border of the Silvretta Nappe (Fig. 1; Froitzheim et al. 1994).

The Gosau sediments of the Inntal Nappe at Muttekopf (Fig. 1) were apparently deposited in a shortening regime (Ortner 2003, 2007). This may represent a local exception from the general transtensional situation. Altogether, Late Cretaceous extensional structures are less obvious and probably less common in the NCA than in the Central Austroalpine to the South. However, some of them may have been reactivated by the intense Tertiary N-S to NNESSW shortening (e.g. Eisbacher and Brandner 1996) and thus escaped recognition. This shortening is in the study area represented by the Austroalpine basal thrust and the postnappe anticline near Brand.

As to the geodynamic reasons for the Late Cretaceous extension and/or subsidence, the following mechanisms have been proposed: tectonic erosion (Wagreich 1995); west-directed rollback of the Penninic subduction zone leading to extension in the upper plate (Froitzheim et al. 1997); and gravitational collapse of thickened continental crust (Willingshofer et al. 1999). The observations presented in this paper strengthen the evidence for extensional deformation but do not allow to distinguish between these mechanisms. In Fig. 13, we suggest a reconstruction of the paleotectonic situation according to the rollback model. Sinistral shear zones to the South and dextral shear zones to the north, in the NCA, bounded a westward-retreating loop of the Penninic-Austroalpine subduction boundary. Thrusting in the Lower Austroalpine, at the front of the orogenic wedge, was contemporaneous with extension in the back. This implies that the change from compressional to extensional deformation occurred at different times in different areas and that in some areas to the east (e.g. Gosau, Weisswasser and Gams), the Gosau basins already started subsiding in an extensional setting during the Turonian (e.g. Faupl and Wagreich 1996), while in our study area, compressional deformation was still taking place. Also contemporaneously with the Late Cretaceous extension, the Cervinia microcontinent (Pleuger et al. 2007) comprising the Margna and Sesia-Dent Blanche Nappes entered the subduction zone, leading to a first stage of highpressure metamorphism around $78 \mathrm{Ma}$ in the Sesia Nappe (Rubatto et al. 2011). Parts of the Piemont-Ligurian ocean stayed open and collision with the Briançonnais did not 
take place before the Paleogene, leading to the emplacement of the Lechtal Nappe on the Falknis, Sulzfluh and other Penninic Nappes along the Austroalpine Basal Thrust.

\section{Conclusions}

1. The belt of steep to vertical bedding along the southern border of the NCA (Arlberg Steep Zone) must be Cretaceous in age, because its structures (D2) are truncated by the Eocene-age Austroalpine Basal Thrust.

2. The Wildberg Syncline, a recumbent "collapse fold," and the low-angle Wildberg normal fault formed together and reflect crustal extension (D3).

3. This phase of extension is most probably Late Cretaceous in age. Late Cretaceous extension, wellknown from the Central and Lower Austroalpine units further south, affected also the NCA, probably in a framework of dextral transtension.

Acknowledgments The authors are indebted to Jörg Fröbisch, Nadine Machalek, Torsten Scheyer and Nadia Stöcker who have carried out diploma mapping projects in the Schesaplana area and thereby provided valuable field data. We thank Jacek Kossak for drafting and two anonymous reviewers for careful and constructive reviews.

\section{References}

Allemann F (1957) Geologie des Fürstentums Liechtenstein (Südwestlicher Teil) unter besonderer Berücksichtigung des Flyschproblems. Jahrb Hist Ver Fürst Liechtenstein 56:1-244

Allemann F (2002) Erläuterungen zur geologischen Karte des Fürstentums Liechtenstein. Regierung des Fürstentums Liechtenstein, Vaduz

Ampferer O (1933) Zur Großtektonik von Vorarlberg. Jahrb Geol Bundesanst 82:31-64

Ampferer O (1934) Geologische Bauformen und Baufragen des Rätikon Gebirges. Jahrb Geol Bundesanst 84:13-40

Arni P (1933) Über tektonische und stratigraphische Probleme im Schesaplana-Lünersee-Gebiet. Eclogae geol Helv 26:93-99

Behrmann JH, Tanner DC (2006) Structural synthesis of the Northern Calcareous Alps, TRANSALP segment. Tectonophysics 414: 225-240

Bertle H, Furrer H, Loacker H (1979) Geologie des Walgaues und des Montafons mit Berücksichtigung der Hydrogeologie. Jber Mitt oberrhein geol Ver (NF) 61:101-115

Conti P, Manatschal G, Pfister M (1994) Synrift sedimentation, Jurassic and Alpine tectonics in the central Ortler Nappe (Eastern Alps, Italy). Eclogae geol Helv 87:63-90

Czurda K, Nicklas L (1970) Zur Mikrofazies und Mikrostratigraphie des Hauptdolomites und des Plattenkalk-Niveaus der Klostertaler Alpen und des Rhätikon (Nördliche Kalkalpen, Vorarlberg). In: Festband 300 Jahre Geol Inst Univ Innsbruck, pp 165-253

Eberli GP (1985) Die Jurassischen Sedimente in den Ostalpinen Decken Graubündens-Relikte eines passiven Kontinentalrandes. Dissertation, ETH Zürich
Eberli GP (1988) The evolution of the southern continental margin of the Jurassic Tethys ocean as recorded in the Allgäu Formation of the Austroalpine nappes of Graubünden (Switzerland). Eclogae geol Helv 81:175-214

Eisbacher GH, Brandner R (1996) Superposed fold-thrust structures and high-angle faults, Northwestern Calcareous Alps, Austria. Eclogae geol Helv 89:553-571

Faupl P, Wagreich M (1996) Basin analysis of the Gosau Group of the Northern Calcareous Alps (Turonian-Eocene, Eastern Alps). In: Wessely G, Liebl W (eds) Oil and gas in Alpidic thrustbelts and basins of Central and Eastern Europe. EAGE Special Publication No. 5, pp 127-135

Frank W (1987) Evolution of the Austroalpine elements in the Cretaceous. In: Flügel HW, Faupl P (eds) Geodynamics of the eastern Alps. Deuticke, Vienna, pp 379-406

Froitzheim N (1988) Synsedimentary and synorogenic normal faults within a thrust sheet of the Eastern Alps (Ortler Zone, Graubünden, Switzerland). Eclogae geol Helv 81:593-610

Froitzheim N (1992) Formation of recumbent folds during synorogenic crustal extension (Austroalpine nappes, Switzerland). Geology 20:923-926

Froitzheim N, Schmid SM, Conti P (1994) Repeated change from crustal shortening to orogen-parallel extension in the Austroalpine units of Graubünden. Eclogae geol Helv 87:559-612

Froitzheim N, Conti P, van Daalen M (1997) Late Cretaceous, synorogenic, low-angle normal faulting along the Schlinig fault (Switzerland, Italy, Austria) and its significance for the tectonics of the Eastern Alps. Tectonophysics 280:267-293

Fügenschuh B, Mancktelow NS, Seward D (2000) Cretaceous to neogene cooling and exhumation of the Oetztal-Stubai basement complex, eastern Alps: a structural and fission track study. Tectonics 19:905-918

Furrer H (1993) Stratigraphie und Facies der Trias/Jura-Grenzschichten in den Oberostalpinen Decken Graubündens. Dissertation, Universität Zürich

Furrer H, Ortner H (2007) Nördliche Kalkalpen. In: Friebe JG (ed) Geologie der österreichischen Bundesländer. Vorarlberg. Geologische Bundesanstalt, Wien, pp 41-48

Handy MR, Herwegh M, Kamber BS, Tietz R, Villa IM (1996) Geochronologic, petrologic and kinematic constraints on the evolution of the Err-Platta boundary, part of a fossil continentocean suture in the Alps (eastern Switzerland). Schweiz Mineral Petrogr Mitt 76:453-474

Handy MR, Schmid SM, Bousquet R, Kissling E, Bernoulli D (2010) Reconciling plate-tectonic reconstructions of Alpine tethys with the geological record of spreading and subduction in the Alps. Earth Sci Rev 102:121-158

Harsch W (1969) Zur Sedimentologie und Paläogeographie der Raibler Schichten (Ober-Trias) im Westteil der Nördlichen Kalkalpen. Z deutsch geol Ges 121:253-272

Heissel W, Oberhauser R, Reithofer O, Schmidegg O (1965) Geologische Karte des Rätikon (1:25 000). Geologische Bundesanstalt, Wien

Hoinkes G, Koller F, Rantitsch G, Dachs E, Höck V, Neubauer F, Schuster R (1999) Alpine metamorphism of the eastern Alps. Schweiz Mineral Petrogr Mitt 79:155-181

Ibele T, Behrmann J (2007) Geologie und Strukturentwicklung der Blankuskopf- und Wildberggruppe im südlichen Brandnertal (Rätikon, Österreich). Vorarlb Naturschau 20:123-154

Jacobshagen V (1965) Die Allgäu-Schichten (Jura-Fleckenmergel) zwischen Wettersteingebirge und Rhein. Jahrb Geol Bundesanst 108:1-114

Janák M, Plašienka D, Frey M, Cosca M, Schmidt ST, Lupták B, Méres Š (2001) Cretaceous evolution of a metamorphic core complex, the Veporic unit, Western Carpathians (Slovakia): P-T conditions and in situ ${ }^{40} \mathrm{Ar} /{ }^{39} \mathrm{Ar}$ UV laser probe dating of metapelites. J Metamorph Geol 19:197-216 
Kobel M (1969) Lithostratigraphische und sedimentologische Untersuchungen in der kalkalpinen Mitteltrias (Anisian und Ladinian) des Rätikon (Österreich und Fürstentum Liechtehstein). Mitt Geol Inst ETH u Univ Zürich (NF) 118

Krohe A (1987) Kinematics of Cretaceous nappe tectonics in the Austroalpine basement of the Koralpe region (eastern Austria). Tectonophysics 136:171-196

Linzer HG, Ratschbacher L, Frisch W (1995) Transpressional structures in the upper crust: the fold-thrust belt of the Northern Calcareous Alps. Tectonophysics 242:41-61

Loacker H (1986) Geologische Beschreibung des Walgaustollens (Vorarlberg, Österreich). Mitt Österr Geol Ges 78:211-213

MacRoberts CA, Furrer H, Jones DS (1997) Palaeoenvironmental interpretation of a Triassic-Jurassic boundary section from Western Austria based on palaeoecological and geochemical data. Palaeogeogr Palaeoclimatol Palaeoecol 136:79-95

May T, Eisbacher GH (1999) Tectonics of the synorogenic "Kreideschiefer basin", northwestern Calcareous Alps, Austria. Eclogae geol Helv 92:307-320

Nagel TJ (2006) Structure of Austroalpine and Penninic units in the Tilisuna area (Eastern Rätikon, Austria): Implications for the paleogeographic position of the Allgäu and Lechtal nappes. Eclogae geol Helv 99:223-235

Neubauer F, Dallmeyer RD, Dunkl I, Schirnik D (1995) Late Cretaceous exhumation of the metamorphic Gleinalm dome, Eastern Alps: kinematics, cooling history and sedimentary response in a sinistral wrench corridor. Tectonophysics 242:79-98

Neubauer F, Genser J, Handler R (2000) The Eastern Alps: result of a two stage collision process. Mitt Österr Geol Ges 92:117-134

Nowotny A, Pestal G, Rockenschaub M (1992) Die Landecker Quarzphyllit- und Phyllitgneiszone als schwächer metamorpher Anteil des Silvrettakristallins. Jahrb Geol Bundesanst 135:867872

Oberhauser R (1963) Die Kreide im Ostalpenraum Österreichs in mikropaläontologischer Sicht. Jahrb Geol Bundesanst 106:1-88

Oberhauser R (1970) Die Überkippungs-Erscheinungen des Kalkalpen-Südrandes im Rätikon und im Arlberg-Gebiet. Verh Geol Bundesanst 1970:477-485

Oberhauser R, Rataj W (1998) Geologisch-tektonische Übersichtskarte von Vorarlberg 1:200 000 mit Erläuterungen. Geol Bundesanst und Vorarlberger Landesmuseumsverein, Wien

Ortner H (1994) Die Muttekopfgosau (Lechtaler Alpen, Tirol/ Österreich): Sedimentologie und Beckenentwicklung. Geol Rundsch 83:197-211

Ortner H (2001) Growing folds and sedimentation of the Gosau Group, Muttekopf, Northern Calcareous Alps, Austria. Int J Earth Sci (Geol Rundsch) 90:727-729
Ortner H (2003) Cretaceous thrusting in the western part of the Northern Calcareous Alps (Austria)-evidences from synorogenic sedimentation and structural data. Mitt Österr Geol Ges 94:63-77

Ortner H (2007) Styles of soft-sediment deformation on top of a growing fold system in the Gosau Group at Muttekopf, Northern Calcareous Alps, Austria: slumping versus tectonic deformation. Sediment Geol 196:99-118

Pleuger J, Roller S, Walter JM, Jansen E, Froitzheim N (2007) Structural evolution of the contact between two Penninic nappes (Zermatt-Saas and Combin zone, Western Alps) and implications for the exhumation mechanism and paleogeography. Int $\mathbf{J}$ Earth Sci 96:229-252

Ramsay JG, Huber MI (1987) The techniques of modern structural geology, volume 2: folds and fractures. Academic Press, London

Rantitsch G, Sachsenhofer RF, Hasenhüttl C, Russegger B, Rainer T (2005) Thermal evolution of an extensional detachment as constrained by organic metamorphic data and thermal modeling: Graz Paleozoic Nappe Complex (Eastern Alps). Tectonophysics 411:57-72

Ratschbacher L, Frisch W, Neubauer F, Schmid SM, Neugebauer J (1989) Extension in compressional orogenic belts: the Eastern Alps. Geology 17:404-407

Reithofer O, Schmidegg O, Oberhauser R (1964) Exkursion III/1: Rätikon. Mitt Geol Ges Wien 57:225-242

Rubatto D, Regis D, Hermann J, Boston K, Engi M, Beltrando M, McAlpine SRB (2011) Yo-yo subduction recorded by accessory minerals in the Italian western Alps. Nature Geoscience 4:338-342

Schmidegg O (1955) Zum tektonischen Gefüge des Rätikons I (oberes Rellstal und oberes Brandnertal). Jahrb Geol Bundesanst 98:145-172

Trümpy R (2006) Geologie der Iberger Klippen und ihrer FlyschUnterlage. Eclogae geol Helv 99:79-121

Wagreich M (1995) Subduction tectonic erosion and Late Cretaceous subsidence along the northern Austroalpine Margin (Eastern Alps, Austria). Tectonophysics 242:63-78

Wagreich M, Decker K (2001) Sedimentary tectonics and subsidence modelling of the type upper Cretaceous Gosau basin (Northern Calcareous Alps, Austria). Int J Earth Sci (Geol Rundsch) 90:714-726

Weh M (1998) Tektonische Entwicklung der penninischen SedimentDecken in Graubünden (Prättigau bis Oberhalbstein). Dissertation, Universität Basel

Willingshofer E, Neubauer F, Cloething S (1999) The significance of Gosau-type basins for the Late Cretaceous tectonic history of the Alpine-Carpathian belt. Phys Chem Earth (A) 24:687-695 